\title{
Coral-killing cyanobacteriosponge (Terpios hoshinota) on the Great Barrier Reef
}

Received: 18 December 2010/Accepted: 3 February 2011/Published online: 20 February 2011

(C) Springer-Verlag 2011

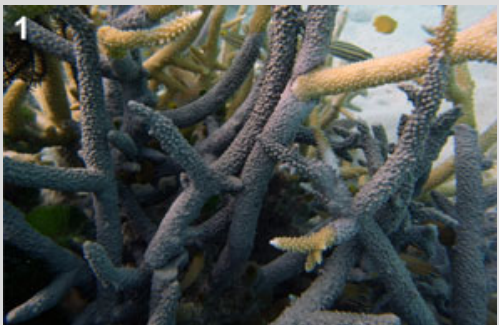

Fig. 1 Acropora colony with $T$. hoshinota at the lagoon of Lizard Island $\left(14^{\circ} 41^{\prime} 52.87^{\prime \prime} \mathrm{S}\right.$, $\left.145^{\circ} 27^{\prime} 13.87^{\prime \prime} \mathrm{E}\right)$

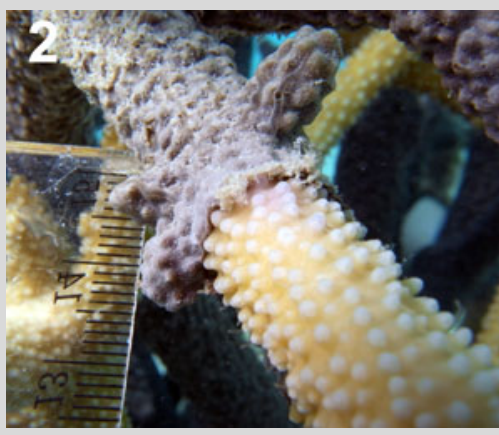

Fig. 2 Close up of the sponge overgrowing live Acropora

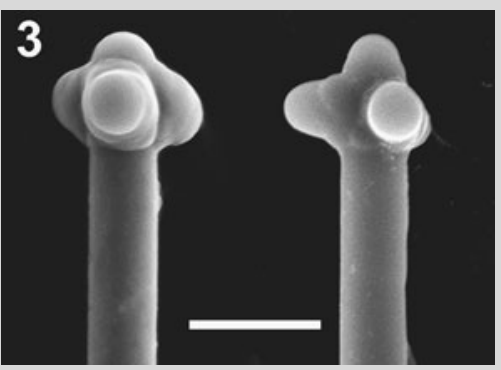

Fig. 3 Spicule heads of $T$. hoshinota observed under scanning electron microscope. Scale $=5 \mu \mathrm{m}$
The encrusting cyanobacteriosponge Terpios hoshinota was originally described from Guam (Rützler and Muzik 1993) and is expanding its range in coral reefs of the northwestern Pacific (Liao et al. 2007). Terpios hoshinota encrusts many hard substrates, including live coral, and occasionally undergoes massive outbreaks that can cover huge areas, which can result in the mass mortality of corals and other resident organisms (Bryan 1973; Rützler and Muzik 1993). This sponge presents a potentially serious threat to coral reefs, and data are needed on its current distribution and abundance to assess its geographical expansion.

In September 2010, sponges resembling T. hoshinota were found on the coral reef of Lizard Island, Australia, growing over live Acropora corals (Figs. 1, 2). Upon preservation in ethanol, the solvent turned green, indicating the presence of cyanobacteria. Further examinations utilizing both internal transcribed spacer 1 (ITS-1) ribosomal DNA sequences (data not shown) and light and electron microscopy (Fig. 3) to examine spicules confirmed the identity of this sponge as $T$. hoshinota. This is the first record of T. hoshinota from the Great Barrier Reef and indicates that this potentially destructive species may be expanding its range into the southeastern Pacific, or has gone undetected until now. Terpios hoshinota distribution in the Great Barrier Reef and central Indo-Pacific should be investigated to assess risks posed by this species to the highly diverse coral reefs in these regions.

Acknowledgments Ocean Exposition Commemorative Park Management Foundation, Okinawa (EH, JDR); Census of Coral Reef Ecosystems (CReefs) Australia Project (TF, JDR). Academia Sinica postdoctoral fellowship (2010-2012) (SK). National Science Council, Taiwan (NSC-98-2321-B-001-024-MY3) and Academia Sinica Thematic Grant (2008-2010) (CAC).

References

Bryan P (1973) Growth rate, toxicity, and distribution of the encrusting sponge, Terpios sp. (Hadromerida: Suberitidae) in Guam, Mariana Islands. Micronesica 9:237-242

Liao M, Tang S, Hsu C, Wen K, Chen W, Wang J, Meng P, Twan W, Lu C, Dai C, Soong K, Chen C (2007) The "black disease" of reef-building corals at Green Island, Taiwan-outbreak of a cyanobacteriosponge, Terpios hoshinota (Suberitidae: Hadromerida). Zool Stud 46:520

Rützler K, Muzik K (1993) Terpios hoshinota, a new cyanobacteriosponge threatening Pacific reefs. Sci Mar 57:395-403

T. Fujii · E. Hirose

Department of Engineering and Science, Faculty of Science, University of the Ryukyus, 1 Senbaru, Nishihara, Okinawa 903-0213, Japan

S. Keshavmurthy $\cdot$ C. A. Chen

Biodiversity Research Center, Academia Sinica, Nangang, Taipei 115, Taiwan

W. Zhou

Institute of Marine Biology, National Sun Yat-sen University, Kaohsiung 804, Taiwan

C. A. Chen

ARC Centre of Excellence for Coral Reef Studies, James Cook University,

Townsville 4810, Australia

J. D. Reimer $(\bowtie)$

Rising Star Program, University of the Ryukyus, 1 Senbaru, Nishihara, Okinawa 903-0213,

Japan

e-mail: jreimer@sci.u-ryukyu.ac.jp 